\title{
Prospects and Trends in the Brazilian Market for Biologically Sourced Products
}

\author{
Luciana da Silva Madeira',Suzana Borschiver², Nei Pereira Jr. ${ }^{3}$
}

\begin{abstract}
The aim of this paper was to select the most interesting Brazilian biopharmaceuticals, with the best market opportunity for production. The biopharmaceuticals filgrastim, infliximab, somatropin, imiglucerase, betainterferon and factor VIII were selected because they are not produced in Brazil and thus could increase the technological capacity of domestic production. The use of a data mining tool facilitated the results achieved here, using the patents deposited in several banks worldwide as the source information. The prospects and trends of producing biopharmaceuticals in Brazil are of great interest to the country to establish a competitive industry and reduce the vulnerability of the National Health System, such as display windows of opportunity, showing the possibility of moving towards the production of biopharmaceuticals.
\end{abstract}

Keywords: production, biopharmaceuticals, specialty drugs, strategic medication, patents, technological forecasting.

'MSc., Technologist Public Health, Fundação Oswaldo Cruz, Bio-Manguinhos, Rio de Janeiro, Brazil and PhD candidate at Federal University of Rio de Janeiro, Rio de Janeiro, Brazil. Horacio Macedo Avenue, 2030 - Centro de Tecnologia, Bloco E, zip code: 21 94I-909; Cidade Universitária - Rio de Janeiro - RJ - Brazil. E-mail: luciana.madeira@bio.fiocruz.br.Telephone number: +55 21 3882-9543

2PhD;Adjunct Professor at School of Chemistry, Federal University of Rio de Janeiro, Rio de Janeiro, Brazil. Horacio Macedo Avenue, 2030 Centro de Tecnologia, Bloco E, zip code: 2 194I-909; Cidade Universitária - Rio de Janeiro - RJ - Brazil. E-mail: suzana@eq.ufrj.br.Telephone number: +55 2I 2562-7582

${ }^{3} \mathrm{PhD}$; Full Professor at School of Chemistry, Federal University of Rio de Janeiro, Rio de Janeiro, Brazil. Horacio Macedo Avenue, 2030 Centro de Tecnologia, Bloco E, zip code: 21941-909; Cidade Universitária - Rio de Janeiro - RJ - Brazil. E-mail: nei@eq.ufrj.br.Telephone number: +55 21 2562-7644

ISSN: 07 I8-2724. (http://www.jotmi.org)

Journal of Technology Management \& Innovation (C) Universidad Alberto Hurtado, Facultad de Economía y Negocios. 


\section{Introduction}

The biotech industry is currently considered to be the most important source of new drug development, in addition to its role as a strategic social and economic sector. The pharmaceutical industry invests millions of dollars each year on research to obtain new products, such as biomolecules, because innovation is the foundation of progress in the health sector. The development of biopharmaceuticals has created treatment options for some of the more complex and frequent diseases, such as multiple sclerosis, Alzheimer's disease, brain tumors, chronic lymphocytic leukemia, and cancer, among many other diseases.

Although the economic aspects of the global pharmaceutical market are changing with the development of biomolecules because of the resulting biotechnology knowledge and employment opportunities, biopharmaceuticals are still a minor portion of the total pharmaceutical market. The market is profitable, but rapid growth is necessary to rapidly and effectively produce new biological drugs, also known as biopharmaceuticals, that have the same clinical application with equal safety, quality and efficiency. Thus, any technical modification may be evaluated using criteria acceptable to regulatory agencies.

In Brazil, the Unified Health System (Sistema Único de Saúde - SUS) and the policy of the Ministry of Health (Ministério da Saúde - MS) according to decree GM/MS no 2.98I of November 26, 2009 require access for the population to specialized medicine, including some biopharmaceuticals.
The attending specialist may prescribe drugs to patients with rare or chronic diseases or diseases that require special treatment, such as Gaucher's disease, rheumatoid arthritis and multiple sclerosis. These medications are divided into three groups based on their characteristics and forms, with responsibility of different organization acquisition, such as the Federal, States and Cities of Brazil.The criterion for the division of the groups involves the complexity of the disease to be treated, including the implications of care and financial maintenance at the various levels of disease management. According to decree GM/MS no 2.98I/2009, the Group I has a great economic impact in Brazil because this group is the responsibility of the federation for treating diseases with greater complexity, and drugs to treat diseases have a significant financial impact.

Sectorial policies directed by the federation through the SUS require access for the Brazilian population to drugs with a major financial impact for the Ministry of Health. As shown in Figure I, expenditures on specialized medicines has grown every year; in $201 \mathrm{I}, 31 \%$ of the total amount spent on medicine (strategic, basic biopharmaceuticals, oncology, among others) was directed to this specialized class of medications.

The "Complexo Industrial da Saúde or CIS" (Industrial Health Complex) is a cornerstone of the Brazilian program of action "Mais Saúde" (More Health).This front is intended to boost the industry, including the domestic pharmaceutical and healthcare equipment sectors, to reduce Brazil's dependence on imported products. Among its goals is to reduce the trade deficit to US $\$ 4.4$ billion to develop tech-

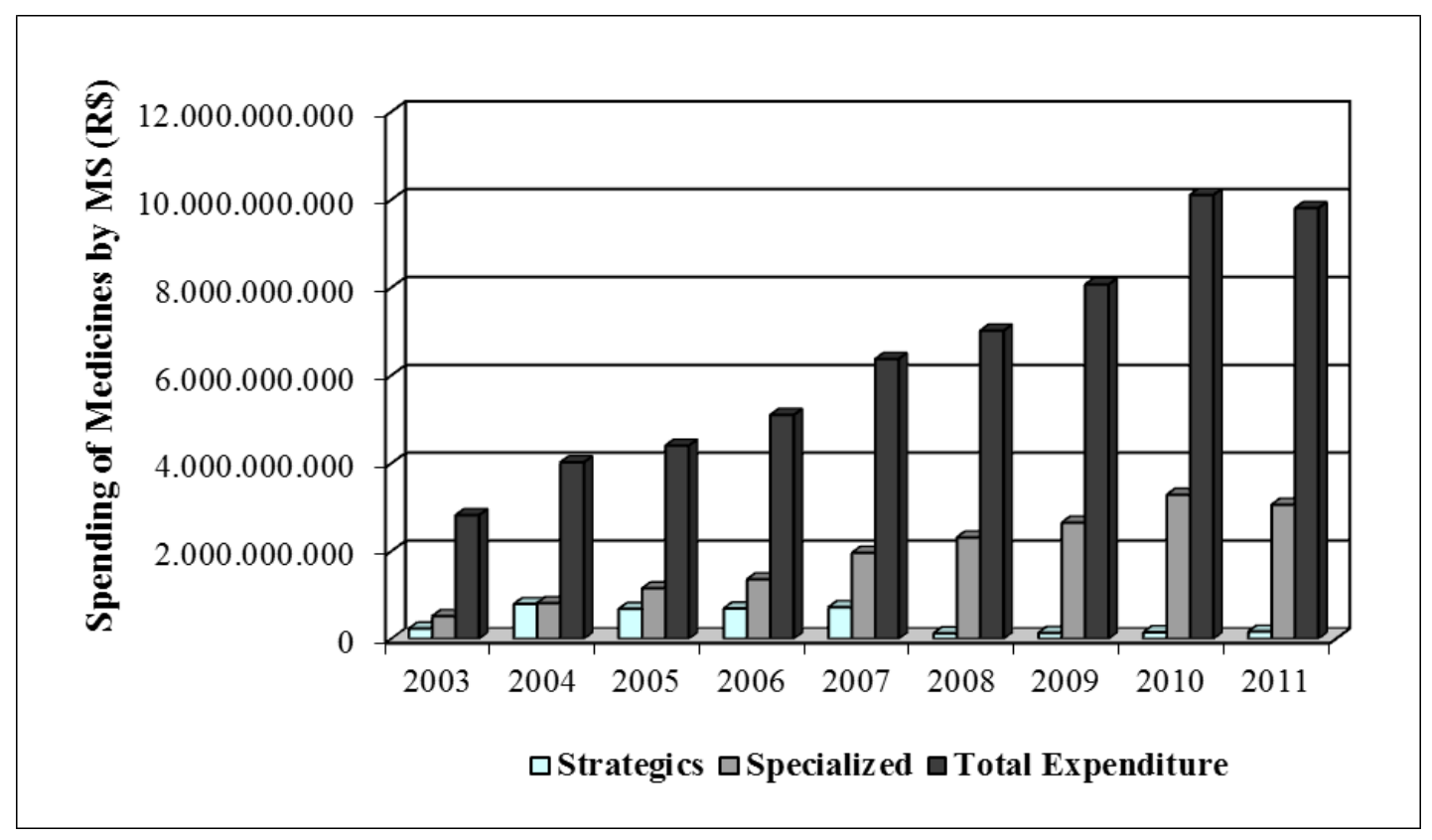

Figure I:The evolution of expenditures on medicines by the Ministry of Health. Source:Analysis DECIIS / SCTIE / MS data SCTIE / MS, SVS / MS and DAF / SCTIE / MS (Moysés Jr, 20II).

ISSN: 07 I8-2724. (http://www.jotmi.org)

Journal of Technology Management \& Innovation (C) Universidad Alberto Hurtado, Facultad de Economía y Negocios. 
nology for the local production of 20 strategic products of SUS to 2013. In 2008, the productive chain of health represented between 7\% and 8\% of the Gross Domestic Product (Produto Interno Bruto - PIB), with mobilized funds of approximately $R \$ 160$ billion of economy in the country (MDIC, 20II). About 10\% of the population is actively employed in the industry. The Brazilian pharmaceutical market annually generates $R \$ 28$ billion, with a high annual growth rate, placing it among the 10 largest in the world. However, these numbers may be even higher in the future because of the Productive Development Policy conducted by the Ministry of Industry and Trade and Development (Ministério da Indústria e Comércio e Desenvolvimento - MDIC), of which the CIS is one of the arms (Portal da Saúde, 20II).

Decree GM/MS nol.284 of May 26, 2010 defines the list of strategic products under the SUS and indicates the key players involved in promoting the CIS strategy, i.e., public and private producers as well as regulators and funding agencies. The decree also indicates which products should be subject to specific initiatives aimed at increasing local production, innovation, technology transfer and regulatory mechanisms. In this ordinance was included the product with purchase cost more than $\mathrm{R} \$ 10$ million, which are purchased with financing of $100 \%$ of MS in decree GM/MS no 2.98 I of November 26, 2009.

To understand the motivation of this study, we must return to the 1990s, when the market opened to foreign companies. This event weakened the Brazilian health industry and increased the trade deficit, which grew from US $\$ 700$ million at the end of the 1980 s to a cumulative US $\$ 7.13$ billion in 2008. Brazil has become extremely dependent on products with a higher density of knowledge and technology. As an example, in 2008 alone, Brazil imported US\$I.4 billion in vaccines, serum and blood products and exported US $\$ 37$ million in products with low added value. Changing this situation requires initiatives to make better quality products in order to be more competitive, improvements in the industrial structure and the formation of public-private partnerships (PPPs), which provide economic and social benefits in return, such as increased industrial parks in the pharmaceutical market that can expand the range of drug treatment and increased specialization of human resources in this area of technology due to the creation of more jobs in the country (Portal da Saúde, 20I I).

\footnotetext{
'The term biosimilar used in Brazil is derived from the translation of the biosimilar, which is the reduction of "similar biological medicinal product" used by the European Agency for the Evaluation of Medicinal Products, EMEA (European Medicines Agency). However, other terms are used for biosimilars in different countries. The United States uses the term "followon protein products", Japan uses the term "follow-on Biologicals", Canada uses the term "subsequent entry biologics", and India uses the term biogenerics, because the generic industry is fairly representative. (Peres, 2009 and Fermam, 2010).
}

\section{I.Volume of Biological Products Marketed}

The health sector requires innovation to progress. The United States understands this need and invested US\$5I.3 billion for research and development in the pharmaceutical industry in 2005, of which US\$18.5 billion went to the development of biopharmaceuticals. It is noteworthy that the biotechnology-based pharmaceutical industry is currently the most important source of new drugs (Roche, 2007).

Both novel molecules and the products known as biosimilar are marketed . According to Gary Walsh (2006), the period from 2003 to 2006 was very interesting for the pharmaceutical industry because the first biosimilar product was approved under the trade name Sandoz Omnitrope ${ }^{\circledR}$ (Novartis group), based on the product Genotropin $®$ from the pharmaceutical company Pfizer, which was formulated with recombinant human growth hormone (recombinant hGH), also known as somatropin. The approval of the drug in Australia in 2005 and later in Europe and the United States in 2006 represents a milestone in this area, though its approval was not without controversy. However, the production of a biosimilar requires the loss of the product's patent protection, and some analysts have suggested that approximately 75 to 2006 approved therapeutic proteins would eventually become targets for the production of a biosimilar. In 2006, the world market had 165 biopharmaceutical products, which received approval in the regulatory agencies worldwide. The total value for the market in 2004 was US $\$ 33$ billion and was estimated to reach US\$70 billion by the end of the decade (actual data not confirmed). In this context, the erythropoietin molecule, also known as erythropoietin, alfaepoetina, recombinant human erythropoietin and EPO, is the biopharmaceutical market leader, reaching US\$10.7 billion in worldwide sales in 2005 (Walsh, 2006). This position was maintained in the United States in 2010 with the commercial product Epogen $\AA$ from Amgen Corporation, the pharma industry leader in biotechnology. Table I presents some data on this vaccine, along with other biopharmaceuticals that are among the 20 most prescribed drugs in this country (Iskowitz and Arnold, 20II).

To understand this industry, Pavlou and Reichert (2004) conducted a survey of the global market for the period from 2005 to 2010, through discussions with executives from pharmaceutical and biotechnology industries. This study revealed that the future growth market for recombinant DNA (rDNA) was the major contributor to the economic prosperity of the global industry. Thus, the leading pharmaceutical companies that market these products expected an increase of US\$19.7 million in 2004 to US $\$ 29.7$ million in 2010 , absorbing $57 \%$ of the total market size of biotechnology. The actual data so far have not been confirmed.

ISSN: 07 I8-2724. (http://www.jotmi.org)

Journal of Technology Management \& Innovation @ Universidad Alberto Hurtado, Facultad de Economía y Negocios. 


\begin{tabular}{|c|c|c|c|c|c|}
\hline Position & $\begin{array}{c}\text { Trade Name of } \\
\text { Product }\end{array}$ & API* & $\begin{array}{c}\text { Pharmaceutical Com- } \\
\text { pany }\end{array}$ & $\begin{array}{c}\text { Sales in } \\
\mathbf{2 0 0 9} \\
\text { (US\$ Bil- } \\
\text { lions) }\end{array}$ & $\begin{array}{c}\text { Sales in } \\
\mathbf{2 0 1 0} \\
\text { (US\$ Bil- } \\
\text { lions) }\end{array}$ \\
\hline $\mathbf{1 0}^{\mathbf{a}}$ & Epogen ${ }^{\circledR}$ & Erythropoietin & Amgen & 3.2 & 3.3 \\
\hline $\mathbf{1 1}^{\mathbf{a}}$ & Remicade ${ }^{\circledR}$ & Infliximab & J\&J/ Merck & 3.2 & 3.3 \\
\hline $\mathbf{1 2}^{\mathbf{a}}$ & Enbrel ${ }^{\circledR}$ & Etanercept & Pfizer & 3.3 & 3.3 \\
\hline $\mathbf{1 4}^{\mathbf{a}}$ & Avastin ${ }^{\circledR}$ & Bevacizumab & Roche & 3.0 & 3.1 \\
\hline $\mathbf{1 6}^{\mathbf{a}}$ & Neulasta ${ }^{\circledR}$ & Pegfilgrastim & Amgen & 3.0 & 3.0 \\
\hline $\mathbf{1 8}^{\mathbf{a}}$ & Humira ${ }^{\circledR}$ & Adalimumab & Abbott & 2.5 & 2.9 \\
\hline $\mathbf{2 0}^{\mathbf{a}}$ & Rituxan ${ }^{\circledR}$ & Rituximab & Roche & 2.6 & 2.8 \\
\hline
\end{tabular}

Table I. $*$ API = active pharmaceutical ingredients

Lanthier et al (2008) related the distribution of protein products for sale and the molecular weight due to the similarity of the structural or therapeutic use. Among the products that exceed US $\$ 250$ million in sales, Lanthier et al suggested the following seven classes of products: erythropoietin (EPO), colony stimulating factors granulocyte (G-CSFs), insulin, interferon-beta (IFN-beta), a human Growth Hormone (hGH), interferon-alpha (IFN-alpha) and monoclonal antibodies $(\mathrm{mAb})$. Over $80 \%$ of the therapeutic products marketed in 2006 were the products of these seven classes. Lanthier et al also estimated an increase in the consumption of medicines produced by biotechnology to reach more than a quarter of all spending on prescription drugs by 2010 . Some of these drugs have a higher cost than the daily dose of the drug molecules and can cost between 10 and 20 times the value of the medicine.

\section{Scenario Production of Biosimilars}

Given this scenario for increasing the production of biopharmaceuticals, some companies may join the biotech market after the patents on innovative medicines expire if they have the resources and expertise to produce biosimilars. As occurred with generic medicines, the production of "copies" of biological medicinal products may occur. Specifically, these drugs, called biosimilars, are similar, but not identical to their reference products of comparison (Peres, 2009 and Fermam, 2010).

The development of the biosimilars market is surrounded by several discussions in regulatory agencies around the world (FDA, EMEA, and ANVISA, among others). For generic drugs obtained by chemical synthesis, the information from the clinical trials of the innovator product are acceptable for the generic product and therefore require fewer demands from regulators, thereby promoting the rapid entry of new prod- ucts into the market. However, for biotechnologically produced drugs, the active pharmaceutical ingredients (APIs) are much more complex for the structure and production process. Therefore, the quality assurance, safety and efficacy of biosimilars are still controversial (Fermam, 2010).

The production of biosimilars is an opportunity for technological advancement for Brazil provided that the country have the capability for increase domestic production; thus, already started the debate in agencies public to the establishment and definition of regulatory guidelines to ensure the comparability therapeutic of biosimilar medicinal. Some national companies have already identified this trend, as shown in a 2008 survey from the database of the National Health Surveillance Agency (Anvisa), which was able to identify seven registered national biopharmaceutical companies: Fiocruz, Cristália, Blausiegel, Eurofarma, Silvestre Lab, Aché and Prodotti (Padilha, Kropf and Baetas, 2009 and Fermam, 2010).

\section{Biopharmaceuticals}

The original definition of biopharmaceuticals that was first agreed upon in the 1980s describes biopharmaceuticals as belonging to a class of therapeutic products produced through biotechnology techniques, i.e., by rDNA technology or hybridoma technology, in the case of products based on murine monoclonal antibodies. Thus, a protein to be considered as a biopharmaceuticals, should be evaluated by the bioprocess that was used in its obtaining. Conversely, therapeutic proteins that are obtained by direct extraction from a source, such as the insulin extracted from pancreatic tissue from slaughtered animals and the blood clotting factors extracted directly from blood, are not considered to be a product of biopharmaceuticals. Therefore, we can define a biopharmaceutical drug as a protein or nucleic acid-based 
product used for therapeutic or diagnostic purposes in vivo that is produced by processes that do not involve the direct extraction from a biological source (Walsh, 2002).

Therapeutic proteins can be classified into seven distinct groups: cytokines, hematopoietic growth factors, other growth factors, hormones, enzymes, clotting factors and monoclonal antibodies. These proteins often have complex structures, such as proteins that require post-translational modifications to achieve their full biological activity, which is essential for their use as a biopharmaceutical. Because of this limitation, most approved biopharmaceuticals are produced by cultivating mammalian cells because microbial cells and insect cells have limitations in their ability to correctly perform the required post-translational modifications (Mellado and Castilho, 2008).

The post-translational modifications generally occur during the synthesis of these molecules, with an $\mathrm{N}$-glycosylation as the most recognized form, and require an extensive number of processing steps that are performed in the endoplasmic reticulum and the Golgi complex. This modification is carried out by eukaryotic cells, which are the most commonly used host for producing biopharmaceuticals. As already stated, mammalian cells exhibit the best metabolic capabilities, in particular, strains of cells from baby hamster kidney cells (BHK) and Chinese hamster ovary cells ( $\mathrm{CHO})$, which have become the preferred host cells in the biopharmaceutical industry because the glycosylation patterns characteristic of these cells are similar to human standards and are considered safe because many of the main viruses that cause disease in humans cannot replicate in them (Butler, 2008).

However, there are also therapeutic non-glycosylated proteins, which are typically expressed in Escherichia coli or Saccharomyces cerevisiae, such as commercial insulin (Humulin ${ }^{\circledR}$ from Eli Lilly), which is obtained from the E. coli, with the same protein expressed in S. cerevisiae marketed as NovoLog® by Novo Nordisk (Gerngross, 2004).

\section{Technologies Employed for the Production of Bi- opharmaceuticals}

Unlike small molecules, which are normally synthesized in the chemical environment, most biopharmaceuticals are sufficiently complex to requiring their production in living systems, particularly by recombinant DNA technology. As such, the choice of host for recombinant expression has been continuously reevaluated, and much effort is directed to developing new expression systems for proteins with improved characteristics. The five major goals in evaluating hosts for the expression of proteins are as follows: the cost of production and purification; the ability to control the final product, including its post-translational processing; the amount of time needed to produce the purified protein from the gene; the agencies' regulatory approval of a drug product produced in a newly developed expression system; and the royalties associated with the global production of a recombinant product in a particular host (Gerngross, 2004). These hosts may be divided into four groups of cells: microbial, mammalian, insect and plant. Biopharmaceuticals are mainly produced by cultivating mammalian cells or animal cells for industrial use, such as $\mathrm{CHO}$ and BHK. However, plants have many advantages compared with traditional systems for producing biopharmaceuticals, including the low production cost, fast scheduling, the absence of human pathogens and the ability to produce complex proteins safely. Studies show that crop plants have been widely studied, with economic and security advantages compared with more conventional systems; furthermore, using plants for synthesizing protein on a large scale is gaining support. The host plants most frequently used are tobacco, cereals, vegetables, fruits and vegetables (Ma, Christou and Drake, 2003).

Controlling the conditions of cell culture is important in producing proteins, and culture conditions, such as nutrient content, $\mathrm{pH}$, temperature and concentrations of oxygen or ammonia, can significantly affect the structures of glycans found in recombinant proteins requiring post-translational modification ( $\mathrm{N}$-glycosylation). Thus, this system sensitivity is important to consider in producing biopharmaceuticals because it may result in a great heterogeneity of glycoforms resulting from an incomplete glycosylation process and a significant batch-to-batch variation during the production process. To maintain the product quality, it is important to understand the factors that cause variations in the posttranslational steps.

There are also a number of other possible post-translational protein modifications that can be characterized, such as the addition or removal of small organic waste products. An example is the process of pegylation, e.g., adding polyethylene glycol (PEG) groups, which involves an additional chemical synthesis step on a therapeutic protein to improve its pharmacological properties. This step can affect the structural integrity of the protein and should be monitored during the bioprocess for producing the biopharmaceutical.

The aim of this paper was to select the most interesting Brazilian biopharmaceuticals, with the best market opportunity for production among those products on the lists of drugs and specialized strategic products in the ordinances of the Ministry of Health. Provide reliable information that could, say, point towards windows of opportunity (e.g. regarding the expiration of the patents rights) may be contribution to the technologic knowledge where they found some biosimilar drugs target that will be useful for the Brazilian health/ drug industry using the patents database focusing in goals 
that could be manufacturer in a near future to enhance the competitive industry and develop technologies that improve changes in the needs of Brazilians.

\section{Method}

\section{Selection of Biological Products}

Selecting the biological products of Brazilian interest occurred after defining the three major criteria. The first criterion for this study is based on the product list consisting of 83 strategic products and selecting the drugs obtained by biological routes (Decree GM/MS nol.284 of May 26, 2010). The second criterion was based on the list of 20 drugs with the highest values approved by the MS in 2007 (Barbano, 2008). Finally, to complement the choice of organic products of interest to this study, the third criterion was based on drugs form the centralized procurement of the Ministry of Health of Brazil but that are not distributed by Brazilian producers (GM/MS no $2.98 \mathrm{I}$ of 26 November, 2009).

\section{Main technical and market information}

Information on biopharmaceuticals was obtained from consistent sources of information, derived from scientific (scientific articles, MSc dissertations and PhD theses) and production technology (patents deposits at the Instituto Nacional da Propriedade Industrial/ INPI and United States Patent and Trademark Office / USPTO). We evaluated information on the website of the Ministry of Health of Brazil, the websites of National and International Research Centers, the website of the World Health Organization (WHO), the websites of producers of biopharmaceuticals, documents of National and International Regulatory Agency and the current legislation in Brazil.

\section{Evaluation of Patents}

After defining the targets of interest, the patents for selected organic products were analyzed to verify the possibility of producing them in Brazil and to evaluate the possibility of a future owner of the technology.

To evaluate the deposition priority in Brazil, the online patent database was searched, which contains the INPI published papers since 1992, plus some patents in previous years. As a strategic search for data collection, we used the "advanced search" function with the name of the vaccine and its synonyms in the "title" and "abstract". The synonyms were obtained through a program developed by Scifinder the Chemical Abstract Service (CAS) for use by researchers in life sciences and materials sciences.
To complement the assessment of technological production, the study was based on the search for the patent database Derwent Innovations Index / DII (Thomson Scientific / ISI Web Services) to select the documents deposited in the USPTO, using the "topic" with the name of the selected biological product and its synonyms for the documents made available until $9 / 29 / 20 \mathrm{II}$. This survey was conducted in the database of granted patents (Patent Full-Text and Image Database / PatFt) with documents since 1976 and requested patents (Patent Application Full-Text and Image Database / AppFt) with requests from $200 \mathrm{I}$.

The USPTO was searched using the following steps: (I) search and extract patents in the database, (2) structure a database of selected patents, (3) import the data into a text mining program, and (4) analyze the information by generating networks. Steps 3 and 4 were performed using Vantage Point version 7.I because of its tools for text mining and correlating significant sets of structured textual data, such as databases, that can extract duplicate information to define variables and construct tables and graphs.

\section{Results and Discussion}

The biological products selected for this study are listed in Table 2. Products that are not produced in Brazil were chosen because the purpose of this work is to produce biopharmaceuticals that contribute to the technological advancement and empowerment of national production with high added value products.

The list of drugs from the centralized procurement specialist already lists the betainterferon drugs imiglucerase and infliximab. However, these drugs are also present on the strategic biopharmaceutical drug list described as being imiglucerase betainterferon glucocerebrosidase and the group of interferons. Additionally, somatotropin, filgrastim and factor VIII, which is a procoagulant factors, are also considered strategic products for the MS. The MS list of 20 approved drugs with higher values in 2007 include the proteins betainterferon, infliximab, somatropin (or somatotropin) and imiglucerase. All of the organic products listed in Table 2 are not produced in the country, so they can be considered a market opportunity for production in Brazil.

Another very important consideration is the expenditures of the Ministry to acquire these drugs, as well as the quantity of purchased product to meet the Brazilian population's demand.Table 3 shows the quantities and amounts approved

\footnotetext{
${ }^{2} \mathrm{~A}$ process for extracting knowledge from large data banks using artificial intelligence techniques to find agreements/disagreements among entries, or groups of them, looking for patterns, anomalies, rules, etc. rendering data as useful information for decision making or evaluation of results.
} 


\begin{tabular}{|c|c|c|}
\hline Biopharmaceutical & Therapeutic Class & Indication \\
\hline Betainterferon & Cytokine & Multiple sclerosis \\
\hline Factor VIII & Blood clotting factor & Control and prevention of bleeding for patients with Hemophilia A \\
\hline Filgrastim & Growth factor & Neutropenia (low neutrophil count) \\
\hline Imiglucerase & Enzyme & Gaucher's disease \\
\hline Infliximab & Monoclonal antibody & $\begin{array}{c}\text { Rheumatoid arthritis, psoriatic arthritis, ulcerative colitis and Crohn's } \\
\text { disease }\end{array}$ \\
\hline Somatropin & Hormone & Deficiency of growth hormone (hGH) and Turner syndrome \\
\hline
\end{tabular}

Table 2:The biological products selected for study

for each vial of biological product in 2009. From these data, it is possible to understand why biopharmaceuticals imiglucerase (or glucocerebrosidase) and infliximab are both present on the list of strategic medicines. Although the amount of somatropin acquired exceeds that of all other biopharmaceuticals presented, the cost to purchase and infliximab imiglucerase is far superior to this hormone.An increased need for these biological products could have a severe impact on the budget of the MS, which could compromise investments in health in other areas.

Identifying the producers of biopharmaceuticals, and therefore the technical information for the production thereof, is very important for directing future investments in industrial technologies. Thus, Table 4 presents some elements for a research line of biotechnological processes. We can then see that the drugs listed in Table 3 with the highest costs are from one global supplier. Therefore, a new producer entering the market may lead to a decrease in the value of the unit price of each vial and therefore produce a great benefit for patients using these drugs. This statement is confirmed by evaluating factor VIII and the biopharmaceutical somatropin because these two biological products have a low unit value and are brought to market by at least four world producers. The biopharmaceutical betainterferon is shown in Tables 3 and 4 in two forms, Ia and I $\mathrm{l}$, and this term depends on the expression system used in its production. The difference in the molecular weight of the forms of the biopharmaceutical obtained at the end of the process may be approximately 22,500 Daltons or 18,500 Daltons, for betainterferon Ia and betainterferon Ib, respectively. This difference in the structure of the molecule is very important for defining the biopharmaceutical purification process.

It is important to mention that the value shown in Table 3 for the organic product filgrastim, which was purchased by the MS in 2009 , is related to the drug in its simplest form of presentation under the trade name Neupogen $\AA$, i.e., the first-generation filgrastim commercial product. The drug Neulasta ${ }^{\circledR}$ is the second-generation injectable, costing about $R \$ 2,000$, and is produced with a post-translational modification known as pegylation. This technique decreases the interval of drug dosing for the patient, requiring only a daily injection of a $6 \mathrm{mg}$ under the skin after about 24 hours of the cycle of chemotherapy, which allows the drug to be released slowly in the body. However, the drug Neupogen $\circledast$ should be administered with greater frequency as determined by medical staff.

Biological products can be produced after the first patent expires, so the expected number of biosimilars is expected to increase after the release period of the first generation of biologically sourced drugs, which started in the mid-1980s, expires. Figure 2 shows a graph with the temporal end of the patent. The patents for the products Cerezyme ${ }^{\circledR}$ (imigluc-

\begin{tabular}{|c|c|c|c|}
\hline Biopharmaceutical & $\begin{array}{c}\text { Amount Approved in } \\
\text { Vial }\end{array}$ & $\begin{array}{c}\text { Approved for Acquisition Value } \\
\text { (R\$) }\end{array}$ & $\begin{array}{c}\text { Value Vial } \\
\text { (R\$) }\end{array}$ \\
\hline Betainterferon 1a & 428,879 & $149,924,809.89$ & 349.57 \\
\hline Betainterferon 1b & 279,285 & $40,182,512.00$ & 143.88 \\
\hline Factor VIII & 115,032 & $620,022.48$ & 5.39 \\
\hline Filgrastim & 106,058 & $3,287,798.00$ & 31.00 \\
\hline Imiglucerase & 124,518 & $180,375,000.00$ & $1,448.59$ \\
\hline Infliximab & 40,331 & $59,248,043.76$ & $1,460.04$ \\
\hline Somatropin & $1,956,710$ & $42,943,698.00$ & 21.95 \\
\hline
\end{tabular}

Table 3: Expenditures of the MS in 2009 in purchasing the biological products selected for the study.

ISSN: 07I 8-2724. (http://www.jotmi.org)

Journal of Technology Management \& Innovation (c) Universidad Alberto Hurtado, Facultad de Economía y Negocios. 


\begin{tabular}{|c|c|c|c|c|}
\hline Biopharmaceutical & \begin{tabular}{|l|} 
Com m e r c i a l \\
Product
\end{tabular} & Manufacturer & $\begin{array}{l}\text { Expression Sys- } \\
\text { tem }\end{array}$ & Protein Group \\
\hline Betainterferon 1a & $\begin{array}{l}\text { Avonex }{ }^{\circledR} \\
\text { Rebif® }\end{array}$ & $\begin{array}{l}\text { Biogen Idec } \\
\text { Serono/ Pfizer }\end{array}$ & $\begin{array}{l}\mathrm{CHO}^{1} \\
\mathrm{CHO}^{1}\end{array}$ & Glycoprotein \\
\hline Betainterferon 1b & $\begin{array}{l}\text { Extavia }{ }^{\circledR} \\
\text { Betaferon }{ }^{\circledR} \\
\text { Betaseron }{ }^{\circledR}\end{array}$ & $\begin{array}{l}\text { Bayer/ Novartis } \\
\text { Schering }\end{array}$ & $\begin{array}{l}\text { Escherichia coli } \\
\text { Escherichia coli }\end{array}$ & Glycoprotein \\
\hline Factor VIII & $\begin{array}{l}\text { Advate }{ }^{\circledR} \\
\text { Helixate }{ }^{\circledR} \\
\text { Kogenate }{ }^{\circledR} \\
\text { Rocombinate }{ }^{\circledR} \\
\text { Refacto }{ }^{\circledR}\end{array}$ & $\begin{array}{l}\text { Baxter } \\
\text { CSL Behring } \\
\text { Bayer } \\
\text { Baxter } \\
\text { Wyeth }\end{array}$ & $\begin{array}{l}\mathrm{CHO}^{1} \\
\mathrm{BHK}^{2} \\
\mathrm{BHK}^{2} \\
\mathrm{CHO}^{1} \\
\mathrm{CHO}^{1}\end{array}$ & Glycoprotein \\
\hline Filgrastim & $\begin{array}{l}\text { Neupogen }{ }^{\circledR} \\
\text { Neulasta }{ }^{\circledR}\end{array}$ & $\begin{array}{l}\text { Amgen/ Roche } \\
\text { Amgen } \\
\end{array}$ & $\begin{array}{l}\text { Escherichia coli } \\
\text { Escherichia coli }\end{array}$ & $\begin{array}{l}\text { Non-glycosylated pro- } \\
\text { tein }\end{array}$ \\
\hline Imiglucerase & Cerezyme ${ }^{\circledR}$ & Genzyme & $\mathrm{CHO}^{1}$ & $\begin{array}{ll}\text { Recombinant } & \text { gluco- } \\
\text { cerebrosidase } & \\
\end{array}$ \\
\hline Infliximab & Remicade ${ }^{\circledR}$ & $\begin{array}{l}\text { Centocor Ortho } \\
\text { Biotec Inc. } \\
\end{array}$ & $\begin{array}{l}\text { Recombinant cell } \\
\text { line }\end{array}$ & $\begin{array}{l}\text { Chimeric monoclonal } \\
\text { antibody }\end{array}$ \\
\hline Somatropin & $\begin{array}{l}\text { Genotropin }{ }^{\circledR} \\
\text { Humatrope }{ }^{\circledR} \\
\text { Norditropin }{ }^{\circledR} \\
\text { Ominitrope }{ }^{\circledR} \\
\text { Nutropin }{ }^{\circledR} \\
\text { Saizen }{ }^{\circledR} \\
\text { Hypertropin }{ }^{\circledR} \\
\text { Serostim }{ }^{\circledR} \\
\text { Jintropin }{ }^{\circledR} \\
\text { Zomacton }{ }^{\circledR}\end{array}$ & $\begin{array}{l}\text { Pfizer } \\
\text { Eli Lilly } \\
\text { Novo Nordisk } \\
\text { Sandoz } \\
\text { Genentech } \\
\text { Merck Serono } \\
\text { NeoGenica Bioscience } \\
\text { Serono } \\
\text { GeneScience Pharmaceuticals } \\
\text { Ferring Pharmaceuticals }\end{array}$ & $\begin{array}{l}\text { Escherichia coli } \\
\text { Escherichia coli } \\
\text { Escherichia coli } \\
\text { Escherichia coli } \\
\text { Escherichia coli } \\
\text { Mouse C127 } \\
\text { Escherichia coli } \\
\text { Mouse C127 } \\
\text { Escherichia coli } \\
\text { Escherichia coli }\end{array}$ & Polypeptide hormone \\
\hline
\end{tabular}

Table 4: Identifying the technological interest in selected biopharmaceuticals. $\mathrm{ICHO}=$ Chinese hamster ovary cells $/ 2 \mathrm{BHK}=$ baby hamster kidney cells 


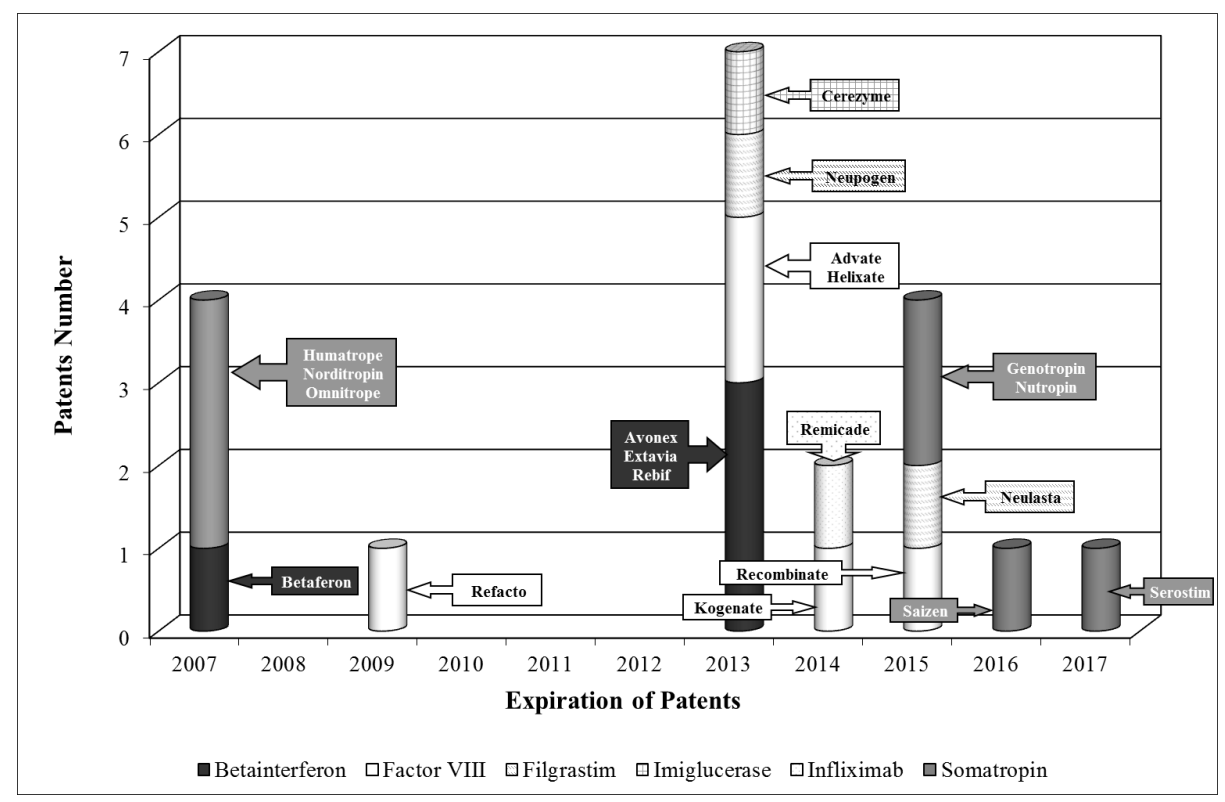

Figure 2:The timeline for the expiration of patents for the commercial products of interest.

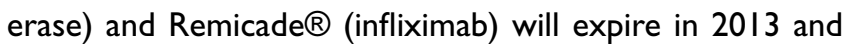
2014 , respectively. With these data, it is possible to imagine that many biosimilars will enter the market soon to compete with these products of high added value.

However, a biosimilar product is faced with not only the problem of obtaining a protein that replicates the structure and conformation of the original product but also the difficulty in achieving the recording the product not innovative. Long, costly clinical studies should be performed to compare the original and the biopharmaceutical biosimilar, which makes the process of biosimilars very difficult from a practical point of view. A major challenge in obtaining the approval of regulatory agencies worldwide is the analytical characterization of the translational modifications that occur in proteins, particularly the processes of glycosylation (addition of carbohydrate molecules) and phosphorylation (phosphate esterification reactions). However, these hindrances do not prevent the production of biosimilar products; otherwise, there would not be as many different commercial products for somatropin and factor VIII produced from different expression systems (Table 4). Nevertheless, a biosimilar may not always be much less costly than the original biopharmaceutical, as occurred with the introduction of generic medicines in the Brazilian market.

However, biosimilars are not the only means of addressing the demands of the population in need of expensive biological products. A country must be able to maintain effective technological development to meet the needs of the nation and thus to achieve market innovations in order to grow and leverage the industry's competitiveness in the country and the world, taking bolder steps toward economic and social progress.
Brazil's goal should be to not be dependent on a single drug so that the population does not suffer from technological backwardness, which was established in the country after the market opened to foreign companies. An example of a biological product that has caused great inconvenience to the country and the world is the drug Cerezyme ${ }^{\circledR}$ (imiglucerase), whose production was interrupted in 2010. A viral contamination of the equipment used to produce the medicinal plant in Allston in the United States was identified, and the U.S.Agency for the Control of Drug Administration (FDA) temporarily suspended its production in June 2009, which compromised the supply of Cerezyme ${ }^{\circledR}$, and patients who required the treatment had their medication dosage reduced in Brazil to reduce the demand for the period (Cerezyme, 2010).

Alternatively, because of the possible contamination of expression systems traditionally used by the pharmaceutical industry, such as mammalian $\mathrm{CHO}$ cells, some research centers are exploring the use of plants or plant cells to produce pharmaceuticals. The enzyme glucocerebrosidase is being produced by an Israeli company Protalix Biotherapeutics from carrot cells, which is in a phase III clinical trial phase (Kaiser, 2008). Additionally, plant cells offer several advantages in producing a vaccine, such as a low production cost, fast scheduling, and the absence of pathogens, making them capable of producing complex proteins safely because they retain the initial stages of post-translational modification $(\mathrm{N}$ glycosylation). However, its modification of the oligosaccharide and the further processing of glycans in the Golgi apparatus differ from those in mammalian cells (Butler, 2008). To complement the INPI patents with priority in Brazil

ISSN: 07 I8-2724. (http://www.jotmi.org) 
showed that inventors observe the country as a future owner of technology and potential consumer market. However, the Instituto Nacional de Propriedade Intelectual does not have a database that represents the full technological deposits, as can be seen in the number of patents filed during the period since 1987 (Table 5). To understand how the production is linked to global technology, this study focused on patents in the USPTO, looking at not only granted patents but also patent applications that may contribute to future trends in producing biopharmaceuticals.

The database Derwent Innovations Index was used to achieve integration and program support for the Vantage Point text mining because of the large amount of data available for this study. However, the patents could also have been surveyed manually using the bank's own data, which

\begin{tabular}{|c|c|c|}
\hline Biopharmaceutical & INPI & USPTO $^{(*)}$ \\
\hline Betainterferon & 27 & 362 \\
\hline Factor VIII & 52 & 595 \\
\hline Filgrastim & 1 & 0 \\
\hline Imiglucerase & 7 & 103 \\
\hline Infliximab & 1 & 14 \\
\hline Somatropin & 12 & 154 \\
\hline
\end{tabular}

Table 5:The number of patents deposited in the INPI and USPTO (*) Patent Full-Text and Application Full Text.

is available by the USPTO if the number of documents is in the dozen.

The USPTO database is used to provide a larger degree of technological foresight to study each of the six selected biological products and thus to trace the technological trajectory that was used after diagnosing a concrete platform technology for the production these drugs.

A more detailed study is presented in Figure 3, showing the network between patents granted and applied for on glucocerebrosidase. We note that some patents have no connection with others, meaning that the state of the art of these patents was probably not important for generating knowledge at that time. However, the cluster that owns the patent-pending US 2005/47567, in Figure 3(B), demonstrates that the information contained in other documents that formed this network is relevant and that it may bring a new product to market.

The patents should be assessed on not only the formation of the network but also the strength of its connection, i.e., how important is one patent to another.This graphical evaluation depicts connections and indicates a stronger connection by the presence of a line. Figure 3(A) shows an example for the granted patent US 6,84I,617 and US 20021 73586 requested. A second example is presented for patents US 6,518,239 and US 20091 17193, in Figure 3(C).

Table 6 shows the relevant information about the selected documents and their importance. Therefore, the primary cluster shown in Figure 3 represents the trend of technological development in the formulation of drugs. This trend is also related to the organic products selected in this article, not only to glucocerebrosidase, because patents are not made exclusively to apply to a single biopharmaceutical.

The graphical information should be evaluated by reading the patent and only those associated patents that had a role in the text mining. Table 6 provides some of the relevant information about the available patents cited in Figure 3.

Patent US 6,518,239 shows the importance of pulmonary administration as an alternative route, which may offer several advantages over subcutaneous administration. These advantages include the convenience of patient self-administration, the reduction of potential side effects, the ease of administration by inhalation, the disposal of needles and so forth.

Patent US 6,84I,617 created an implant system as a carrier for medicines. The composition of these implants is based on an aqueous solution containing a biodegradable polymer that is easily synthesized and handled and that acts as a promising carrier to promote cell proliferation and biosynthesis, supporting physiological loads. The in situ gelling is based on injection systems and eliminates the need for surgical procedures, offering advantages and the ability to form any required implant patent. US 2002173586, requested in 2002 , was granted a patent US 6,84I,617 in 2005; therefore, the connection between these two documents is quite strong (Figure $3 \mathrm{~A}$ ).

The applications US 2005 I 47567 and US 2009 I I I 93 were licensed as patent US 6,518,239 in 2003. The pharmaceutical composition has a high dispersion and upper inhalable aerosols and is therefore preferred for administration to the 


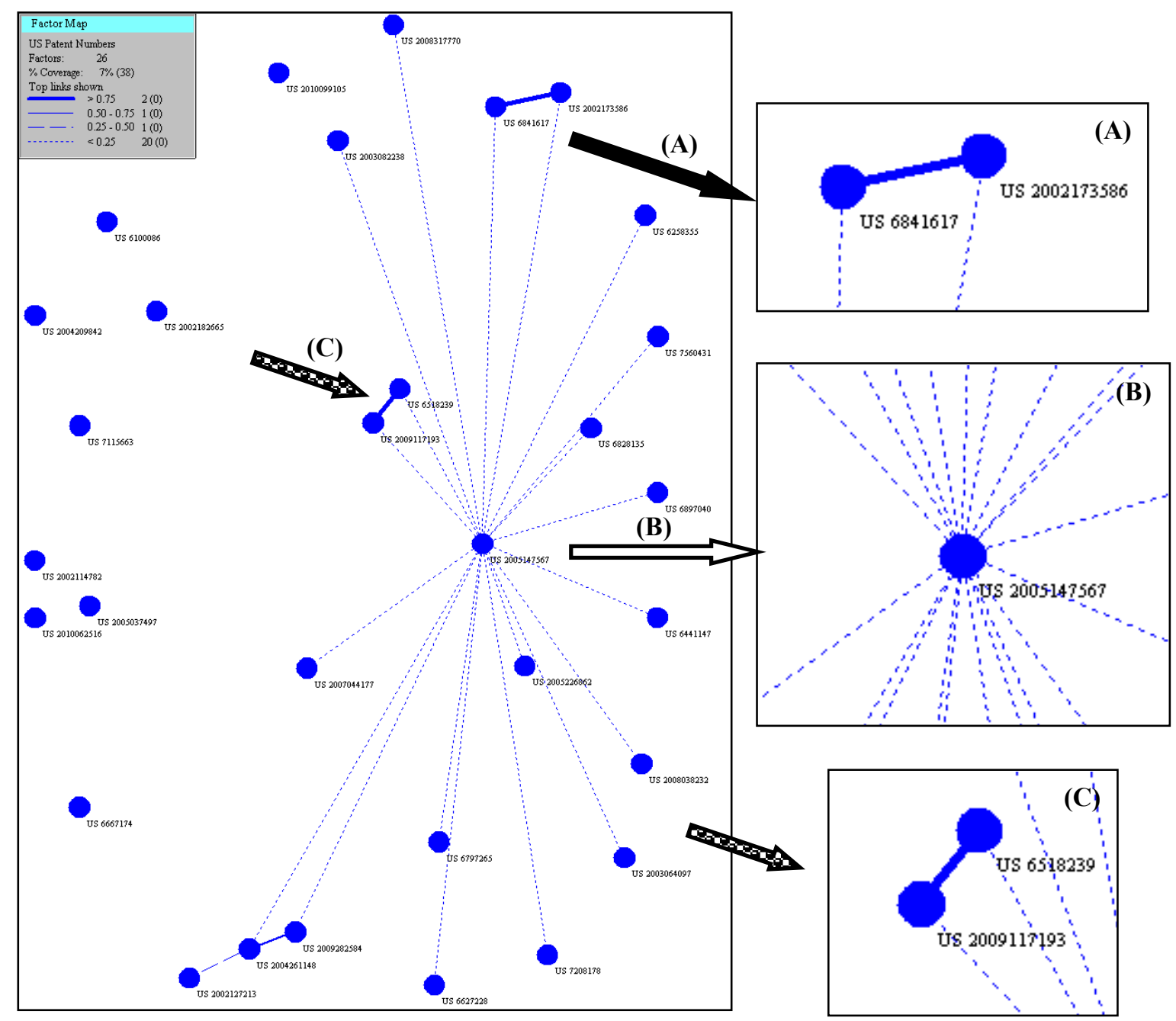

Figure 3: Graph obtained after data mining extracted from the USPTO for patents on glucocerebrosidase using the program Vantage Point. (A) Connection between US 6,84I,6I7 and US 2002I73586; (B) Cluster US 2005I47567; (C) Connection between US 6,5I8,239 and US 2009117193.

lungs. The dry powder contains an active agent and a di-or tripeptide containing at least two leucyl residues. The composition is physically and chemically stable for storage.

\section{Conclusions}

The prospects and trends of producing biopharmaceuticals in Brazil are of great interest to the country to establish a competitive industry and reduce the vulnerability of the National Health System. The importance of obtaining these drugs domestically at lower cost could provide an important foundation for achieving economic and social benefits, such as an increased market share in industrial biotechnology, which expands the range of drug treatment and the specialization of human resources in this technology area. Most important, however, the production of biopharmaceuticals in Brazil would increase the public's access to these specialized drugs for treating rare or chronic diseases as well as those that require special treatment.

But, despite the complexity of the subject matter, producing biological products has become a widely debated topic in both academic and industrial contexts. The challenges involved in producing biological products drive research to answer the questions that arise throughout this work.

The Industrial Health Complex for Brazil needs to strengthen its technology base to succeed in generating competitive pharmaceutical companies. However, the technology base can only be strengthened when technological developments in the country are able to meet market demand. 


\begin{tabular}{|c|c|c|c|c|}
\hline Patent & Title & Year & Assignees & Importance of Patent \\
\hline US 6,518,239 & $\begin{array}{c}\text { Dry powder composi- } \\
\text { tions having improved } \\
\text { dispersivity }\end{array}$ & 2003 & $\begin{array}{l}\text { Inhale Therapeu- } \\
\text { tic Systems, Inc. }\end{array}$ & $\begin{array}{l}\text { Administration of the medication } \\
\text { upon presentation of the aerosol }\end{array}$ \\
\hline US 6,841,617 & $\begin{array}{l}\text { Thermogelling bio- } \\
\text { degradable aqueous } \\
\text { polymer solution }\end{array}$ & 2005 & $\begin{array}{l}\text { Battelle Memorial } \\
\text { Institute }\end{array}$ & $\begin{array}{l}\text { Composition of aqueous biodegrad- } \\
\text { able polymer "thermogelling" and } \\
\text { methods for using polymers to pro- } \\
\text { vide biodegradable implant in situ }\end{array}$ \\
\hline US 2002173586 & $\begin{array}{l}\text { Thermogelling bio- } \\
\text { degradable aqueous } \\
\text { polymer solution }\end{array}$ & 2002 & $\begin{array}{c}\text { Intl Prop Services, } \\
\text { Battelle Memorial } \\
\text { Institute }\end{array}$ & $\begin{array}{l}\text { Composition of aqueous biodegrad- } \\
\text { able polymer "thermogelling" and } \\
\text { methods for using polymers to pro- } \\
\text { vide biodegradable implant in situ }\end{array}$ \\
\hline US 2005147567 & $\begin{array}{l}\text { Compositions com- } \\
\text { prising an active agent }\end{array}$ & 2005 & $\begin{array}{l}\text { Nektar Therapeu- } \\
\text { tics }\end{array}$ & $\begin{array}{l}\text { Administration of the medication } \\
\text { upon presentation of the aerosol }\end{array}$ \\
\hline US 2009117193 & $\begin{array}{l}\text { Compositions Com- } \\
\text { prising an Active } \\
\text { Agent }\end{array}$ & 2009 & $\begin{array}{l}\text { Nektar Therapeu- } \\
\text { tics }\end{array}$ & $\begin{array}{l}\text { Administration of the medication } \\
\text { upon presentation of the aerosol }\end{array}$ \\
\hline
\end{tabular}

Table 6:The relevant information about the selected documents and their importance

Partnerships between academia and public and private sectors should be established to increase the rate of innovation and patent protection in Brazil and to master the scientific and technological knowledge in strategic areas to reduce the vulnerability of the National Health System. Only by collaborating will the country be able to establish a competitive industry for producing medicines for human use.

However, biosimilars are not the only way to meet the needs of the population for expensive biological products. A country must be able to effectively develop technology to meet its needs and thus grow and leverage the competitiveness of its industry in the country and the world in order to facilitate economic and social progress.

\section{Acknowledgements}

We would like to thank Dr. Carlos Morel and Dr. Claudia Ines Chama, both from the Center for Technological Development in Health (Centro de Desenvolvimento Tecnológico em Saúde - CDTS), Oswaldo Cruz Foundation, for providing the program Vantage Point 7.I for use in this work.

\section{References}

BARBANO, D. (2008). Política de Assistência Farmacêutica: contribuição dos setores público e privado. In: Seminário sobre o Complexo Econômico-Industrial da Saúde, Rio de Janeiro. Anais eletrônicos. http://www.bndes.gov.br/ SiteBNDES/export/sites/default/bndes_pt/Galerias/Arquiv- os/conhecimento/seminario/complexo_ind_saude_dirceubarbano.pdf [Accessed September 30, 2009]

BUTLER, M. (2008). Modificações pós-tradução em proteínas recombinantes. In: Moraes A. M.,Augusto E. F. P., Castilho L. R. Tecnologia do Cultivo de Células Animais - de Biofármacos a Terapia Gênica, I22-137. Editora Roca, São Paulo.

CEREZYME (2010). Medicamento para doença de Gaucher terá fornecimento comprometido. http://www.isaude. net/pt-BR/noticia/5805/saude-publica/medicamento-paradoenca-de-gaucher-tera-fornecimento-comprometido. [Accessed September 23, 2010]

DECREE GM/MS No I.284 de 26 de maio de 2010 (2010). Altera o anexo a Portaria No 978/GM/MS, de 16 de maio de 2008. Legislação em Vigilância Sanitária. Brasília. http://portal. saude.gov.br/portal/arquivos/pdf/portaria I 284_0707 I0.pdf. [Accessed January 4, 20I I]

DECREE GM/MS No 2.98 I de 26 de novembro de 2009 (2009). Aprova o Componente Especializado da Assistência Farmacêutica. Legislação em Vigilância Sanitária. Brasília. http://www.brasilsus.com.br/legislacoes/gm/l0 I 556-298I. [Accessed January 4, 20II]

FERMAN, M. K. S. (2010). Capacitação Brasileira para Produção de Medicamentos Biológicos Similares, MSc dissertation of School of Chemistry, Federal University of Rio de Janeiro, Rio de Janeiro. 
GERNGROSS, T.U. (2004). Advances in the production of human therapeutic proteins in yeasts and filamentous fungi. Nature Biotechnology, 22 (II), | 409-I4I4.

ISKOWITZ, M.,Arnold, M. (20II). רברדThe Pharma Report 20I0. Medical Marketing \& Media, 5, 40-46.

KAISER, J. (2008). Is the Drought Over for Pharming? Science, 320, 473-475.

LANTHIER, M., Behrman, R., Nardinelli, C. (2008). Economic issues with follow-on protein products. Nature Reviews Drug Discovery, 7, 733-737.

MA, J. K. C., Drake, P.M.W., Christou, P. (2003). The production of recombinant pharmaceutical proteins in plants. $\mathrm{Na}-$ ture Reviews - Genetics, 4, 794-805.

MDIC (20II). Complexo Industrial da Saúde. http://www. mdic.gov.br/pdp/index.php/politica/setores/complexolndust rialSaude/2I [Accessed November 26, 20I I]

MELLADO, M. C. M, Castilho, L. R. (2008). Proteínas recombinantes terapêuticas. In: Moraes A. M., Augusto E. F. P., Castilho L. R. Tecnologia do Cultivo de Células Animais - de Biofármacos a Terapia Gênica, 384-402. Editora Roca, São Paulo.

MOYSÉS Jr, Z. (20I I).A Nova Política de Compras Governamentais. In:V Seminário sobre Rotas Tecnológicas da Biotecnologia, São Paulo. Anais eletrônicos. http://www.seminariobiotecnologia.com.br/site/biblioteca_midia/zich-moyses. pdf. [Accessed January 27, 2012]

PADILHA, G., Kropf, M., Baetas, R. (2009). Biomedicamentos: copiar é uma estratégia viável para o Brasil? In: GADELHA et al, Política de Inovação em Saúde, Projeto Fiocruz-FiotecOPAS, Rio de Janeiro apud FERMAN, M. K. S. (2010). Capacitação Brasileira para Produção de Medicamentos Biológicos Similares, MSc dissertation of School of Chemistry, Federal University of Rio de Janeiro, Rio de Janeiro.

PAVLOU, A. K., Reichert, J .M. (2004). Recombinat protein therapeutics - success rates, market trends and values to 2010. Nature Biotechnology, 22 (I2), I5I3-I5I9.

PERES, B.S. (2009). Aspectos Relevantes para a Aprovação de Biossimilares, Fiocruz, Rio de Janeiro apud FERMAN, M. K. S. (2010). Capacitação Brasileira para Produção de Medicamentos Biológicos Similares, MSc dissertation of School of Chemistry, Federal University of Rio de Janeiro, Rio de Janeiro.
PORTAL DA SAÚDE (20II). Complexo Industrial da Saúde. http://portal.saude.gov.br/portal/saude/Gestor/visualizar_ texto.cfm?idtxt=32686. [Accessed November 26, 20I I]

ROCHE (2007). Medicamentos Biológicos. http://www. roche.com.br/NR/rdonlyres/ACDF0F9D-355B-42F3-BFFEC7FD I04ABD6E/6488/medicamentosbiologicos.pdf. [Accessed June 20, 2007]

WALSH, G. (2002). Biopharmaceuticals and biotechnology medicines: an issue of nomenclature. European Journal of Pharmaceutical Sciences, 15, I35-138.

WALSH, G. (2006). Biopharmaceutical benchmarks 2006. Nature Biotechnology, 24 (7), 769-776. 